\title{
The Influence of Brand Awareness, Brand Image, and Brand Trust on Brand Loyalty
}

\author{
Innocentius Bernarto ${ }^{1}$, Margaretha Pink Berlianto², Yohana F. Cahya Palupi \\ Meilani $^{3}$, Ronnie Resdianto Masman ${ }^{4}$, and Ian Nurpatria Suryawan ${ }^{5}$ \\ Universitas Pelita Harapan, Indonesia ${ }^{1,2,3}$, \\ Universitas Tarumanagara ${ }^{4}$, \\ STIE Trisakti ${ }^{5}$ Indonesia
}

Email:

bernarto227@gmail.com

\begin{abstract}
The aim of this research is to examine the positive influence of brand awareness, brand image, and brand trust on brand loyalty. The coffee shop business in big cities in Indonesia is growing rapidly. Each coffee shop strives to show its uniqueness. This competition has resulted in them competing to increase competitiveness by using logos, symbols, unique names - or what is usually called a brand to become a differentiator among the competitors. This study was done in a quantitative manner. The data was collected by using a questionnaire distributed using a survey method. Using a snowball sampling, a total of 436 samples were used and analyzed statistically using the partial least square - structural equation modeling (PLS-SEM) approach using SmartPls 3.0 program. The results show that brand awareness and brand trust had a positive effect on brand loyalty. However, the brand image did not have a positive effect on brand loyalty. This study is expected to provide input to the coffee shop management on how to increase their brand loyalty which can be done by increasing their brand awareness, brand image, and brand trust.
\end{abstract}

Keywords: brand awareness, brand image, brand trust, brand loyalty.

Abstrak: Tujuan dari penelitian ini adalah untuk menguji pengaruh positif kesadaran merek, citra merek, dan kepercayaan merek terhadap loyalitas merek. Bisnis coffee shop di kota-kota besar di Indonesia berkembang pesat. Setiap kedai kopi berusaha menunjukkan keunikannya. Persaingan ini mengakibatkan mereka berlomba-lomba meningkatkan daya saing dengan menggunakan logo, simbol, nama unik - atau yang biasa disebut merek untuk menjadi pembeda di antara para pesaing. Penelitian ini dilakukan secara kuantitatif. Data dikumpulkan dengan menggunakan kuesioner yang didistribusikan menggunakan metode survei. Menggunakan snowball sampling, total 436 sampel digunakan dan dianalisis secara statistik menggunakan partial least square-structural equation modeling (PLS-SEM) menggunakan program SmartPls 3.0. Hasil penelitian menunjukkan bahwa kesadaran merek dan kepercayaan merek memiliki efek positif pada loyalitas merek. Namun, citra merek tidak memiliki efek positif pada loyalitas merek. Penelitian ini diharapkan dapat memberikan masukan kepada manajemen coffee shop tentang bagaimana meningkatkan brand loyalty yang dapat dilakukan dengan meningkatkan brand awareness, brand image, dan brand trust.

Kata Kunci: brand awareness, brand image, brand trust, brand loyalty. 


\section{INTRODUCTION}

In Indonesia, franchises of cofee shop business have been the current trend. It is also supported by the fact that Indonesia is one of the producers of coffee or tea in the world, which is also the main raw material for the coffee shops. Indonesia ranks fourth in coffee producers in the world after Brazil, Vietnam, and Colombia. In addition, as consumers, Indonesia also ranks seventh in the world (Directorate General of Estates, 2015). As a result, the development of the café business in Indonesia is highly promising. In 2016, more than ten thousand cafés were open in Indonesia, and the total revenue increased from USD 3.4 billion to USD 4.16 billion in 2013-2018. This condition is predicted to continue to grow up to $30 \%$ ("Potensi bisnis kafe sentuh USD 4,16 milliar", 2016).

In big cities, the development of coffee shop business is also growing rapidly. Several previous studies mention that more and more young people in Indonesia like the trend of visiting coffee shops in their leisure time (Herlyana, 2012; Salendra, 2014). As a result, more entrepreneurs use concepts or ideas to attract customers of various ages and social groups. It is also in line with a statement mentioning that the food business in Indonesia has enormous potential. With an estimated value of IDR 844.35 trillion, all business actors have the same opportunity where most of them $(90 \%)$ are independent (Bella, 2018).

A coffee shop was originally located in a hotel building or mall. However, it has started to shift a lot more simply. A coffee shop provides coffee and tea drinks and even snacks in a relaxed atmosphere with live music or played online. Coffee shops are designed with distinctive interior design, friendly service, and internet connection (Herlyana, 2012). Changes in the coffee shop from an era to another can be seen from the design of the building, concepts and the menu offered which are now getting more modern and diverse (Salendra, 2014). They are not only a place to enjoy coffee and tea, but they have become a part of the lifestyle of the young consumers in Indonesia. Each coffee shop strives to show its uniqueness. This competition has resulted in them competing to increase competitiveness by using logos, symbols, unique names - or what is usually called a brand to become a differentiator among the competitors. The consumers do not only visit cafés for the food and drink but also to have a different experience. For this reason, the café manager must be able to provide the expected experience by implementing the right marketing strategy for young customers by giving a particular touch of sensation and emotions in relation to the brand they are developing.

According to (Aaker, 2015), a brand refers to an asset that has equity and moves the strategy and business performance. A brand with a high positive brand value will help marketers to market the product because the public has a positive perception of the brand. It implies that when a brand has high brand equity, the consumers' intention to buy will also increase. In addition, a brand is also defined as one of the human intellectual works that have a relationship with the economy and play a very important role. Referring to the definition above, a brand also functions as one of the identifiers for one company with another company (Mardianto, 2011). Further, it is also a means of trade promotion and guarantee of goods and services. Developing a strong brand is one of the most important goals of product and brand management. It is mainly because strong brands generate higher income, both in the short and long term (Kotler and Keller, 2016). Thus, brand image is one thing that must be considered. Without a positive image and strong brands, it 
is going to be complicated to attract new customers and maintain the regular ones. The consumer's views and thoughts about a product can lead to trust in the brands and simultaneously lead to consumer loyalty (Rizan, 2012).

This study emphasizes more on brand loyalty because it is an essential factor for the success of long-term relationships that are similar to consumer commitment to a café shop brand. The brand loyalty or commitment owned by a consumer is the result of trust as loyalty or commitment can be defined as the desire to maintain or improve relationships with high quality. Therefore, marketers need to understand the brand concept loyalty (Hawkins, 2013). Further, this study also describes brand awareness and brand trust. It is because brand trust is very potential in forming high-value relationships with consumers (Morgan and Hunt, 1994). There are many kinds of research on brand loyalty such as the ones by (Mao, 2010); (Ika et al., 2011); (Rizan, 2012); (Awan, 2014); (Al-Msallam, 2015). However, only a few of them discuss the café industry with young consumer respondents (college students).

\section{THEORITICAL REVIEW}

Brand awareness, brand image, brand trust, and brand loyalty. According to (Kardes et al., 2010), there are two types of brand loyalty which consist of attitude and behavior. Attitude reflects the overall feel of customers towards the brand, while the behavior is related to the tendency of customers to repeat purchases. The customers often express brand loyalty to products that can improve or show identity. Brand loyalty can be defined as a measure of closeness that consumers feel about a brand. (Aaker, 2015) defined it as a measure of customer loyalty to a brand where it can identify when a customer about to switch to other brands offered by competitors, including changes in prices or other attributes. (Broadbent et al., 2010) defined the brand loyalty as a statement of commitment in relation to the customer loyalty to a product or service which is going to be consistent and be present in the future so that there will be ongoing purchases.

Meanwhile, brand awareness is necessary for developing brand equity (Kotler and Keller, 2016). It refers to the extent to which a consumer can identify a brand. Similarly, (Kotler and Keller, 2016) also argued that brand awareness is related to the strength of brand information that allows marketers to measure consumers' ability to identify brands in various conditions. Further, according to (Aaker, 2015), brand awareness is an asset affecting perceptions, likes, and even consumer behavior. It can bring impacts to purchase decisions about brands which at the end will enhance loyalty (Mathew et al., 2014). Previous studies show that brand awareness had a positive effect on brand image. (Bilgin, 2018); (Permana and Ilham, 2018) confirmed this finding in packaged drinking water product; (Saleem et al., 2015) in the beverage industry; (Schivinski and Dabrowski, 2015) in social media communication; (Su and Chang, 2018) in the fast fashion industry; and Tran, Nguyen, Tran, Tran, and Huynh (2019) in the tourism industry. Besides, the brand awareness was also found to have a positive effect on brand trust (Bart et al., 2005; Bilgin, 2018; Cassia et al., 2017; Das, 2016; Lee and Jee, 2016; Han et al., 2015). Researches by (Alkhawaldeh et al., 2017); (Alkhawaldeh and Eneizan, 2018); (Bilgin, 2018); (Kim, and Petrick, 2018); (Su and Chang, 2018); (Das, 2016); (Su, 2016); (Tran et al., 2019) also supported that brand awareness had a positive influence on brand loyalty. For this reason, hypotheses that can be formulated are as follows: 
H1: The higher the brand awareness, the higher the brand image.

H2: The higher the brand awareness, the higher the brand trust.

H3: The higher the brand awareness, the higher the brand loyalty.

Brand image, brand trust, and brand loyalty. Brand image, according to (Kotler and Keller, 2016), is an assumption about the brand reflected by consumers based on their memories. (Keller, 2013) explained that there are three parts to the measurement of brand image. The first part is the attribute. It is a set of characteristics or various aspects of the brand advertised. It is also divided into two parts, consisting of things that are related and unrelated to the product. The second part is benefits, consisting of functional, symbolic, or experiential aspects. (Aaker, 2007) claimed that functional benefits are the most important benefits of a product. The customers buy a product for its functional benefits. Basically, the functional benefits are a rational reason for customers to buy and consume a product. On the other hand, symbolic benefits are the ones related to prestige (Kotler and Keller, 2009). The customers buy a product not merely looking for its functions, but also for the customers' self-concept. Meanwhile, the experiential benefit is the one that is felt or experienced by the customer when using the product he bought. Finally, the third part is attitude. Attitude is the result of customer evaluation after using a product. The results of the evaluation can be whether or not the customer likes the product (Sangaji and Sopiah, 2013). When the customers do not like or like a product, the feeling will direct the customer behavior to buy or not to buy the product.

When a product has a good image, the customers will increasingly believe that the product is indeed good. This is evident from the results of researches by (Iskandar and Berlianto, 2018), (Chinomona, 2016); (Lee and Jee, 2016); (Liu et al., 2019) which confirmed that brand image could contribute to increasing the customer trust in product brands. Besides, previous researches found that the brand image also had positive effects on brand loyalty (Alkhawaldeh and Eneizan, 2018; Espinosa et al., 2018; Kim et al., 2018; Lee et al., 2017; Lin et al., 2017; Liu et al., 2019; Semadi and Ariyanti, 2018; Tran et al., 2019). Therefore, hypotheses that can be formulated are as follows:

H4: The higher the brand image, the higher the brand trust.

H5: The higher the brand image, the higher the brand loyalty.

Brand trust, and brand loyalty. (Chaudhuri and Holbrook, 2001) defined brand trust as consumers relying on the brand's ability to carry out its functions consistently. Besides, (Ika et al., 2011) defined it as the brand's ability to be trusted or reliable, and it is obtained from the consumers' confidence that the product is capable to meet its promised value. Meanwhile, trust refers to the ability to accept an attribute associated with an object or person (Mahmoudzadeh et al., 2013). It has been seen as a basic and important component or even as a key concept that governs a relationship (Sorayaei and Marjan, 2013). According to (Morgan and Hunt, 1994), trust plays a prerequisite for creating and preserving long-term relationships between companies and customers. (Reichheld and 
Schefter, 2000) stated that trust is the entrance to get customer loyalty. These statements underline that loyalty can be predicted by trust.

Based on the definitions explained above, it can be concluded that trust is the main and important thing in building a relationship between companies and consumers. With the existence of a consumer trust, the consumers are expected to continue to make repeat purchases. The brand trust has been proved as an antecedent factor of brand loyalty. Previous researches show than brand trust had a positive effect on brand loyalty (Chinomona, 2016; Lee and Jee, 2016; Liu et al., 2019; Menidjel et al., 2017; Semadi, and Ariyanti, 2018). Therefore, a hypothesis that can be formulated is as follows:

H6: The higher the brand trust, the higher the brand loyalty.

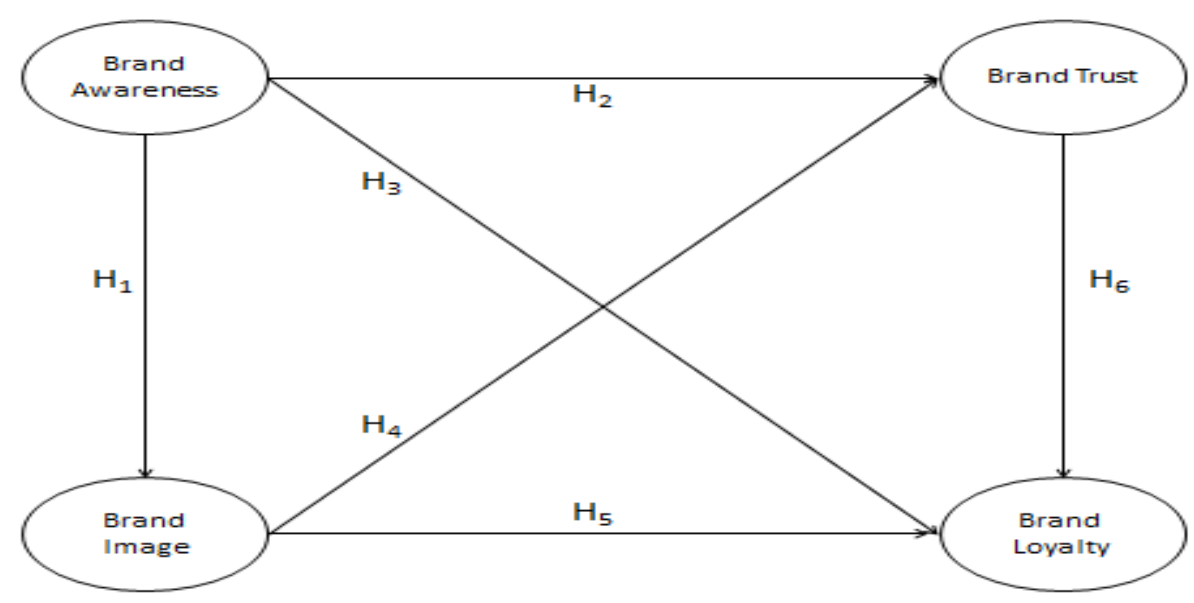

Figure 1. Research Model

\section{METHODS}

In this study, the target population was all customers of coffee shops in Indonesia. The sample was obtained using the snowball technique. The data were collected using a questionnaire. There was a total of 436 respondents involved. The questionnaire was distributed in various cities in Indonesia through smartphones. The data was then analyzed using the PLS-SEM approach using the SmartPLs program. Indicators are measured using 5-Likert scale, where $1=$ strongly disagree; $2=$ disagree; $3=$ neutral; $4=$ agree and $5=$ strongly agree. All indicators were adapted from (Algesheimer et al., 2005); (Aydin et al., 2005); (Chaudhuri and Holbrook, 2001); (Fullerton, 2009); (Mudzakkir and Nurfarida, 2015); (Salciuviene et al., 2009); (Setyawan and Adiwijaya, 2018).

The data analysis consists of outer and inner model analysis. At the outer stage, reliability and validity tests were performed. Reliability testing was done to find out whether the data from the measurement instruments were reliable or not. The data would be considered reliable when the composite reliability value is greater than 0.7 (Hair et al., 2017). Furthermore, the validity testing was done by calculating convergent validity and discriminant analysis. The convergent validity consists of average variance extracted 
(AVE) and outer loading. The criteria that must be met for the validity test are outer loading values should be $>0.708$, and AVE $>0.5$. Furthermore, in the discriminant analysis, the AVE square root value must be greater than the correlation value between constructs. The final stage is the inner model. The procedure carried out in this stage was to estimate collinearity, path coefficient, and significance of the relationship between constructs, and the coefficient of determination. The criterion that must be met for the collinearity is that the value of variance inflation factor (VIF) should be $<5$.

\section{RESULTS}

Respondent Profile. There was a total of 436 respondents involved in this study. There were $51.5 \%$ of male and $48.5 \%$ of female customers. Their age varies, where there are $40.4 \%$ of $18-<22$ years old, $34.7 \%$ of $22-<41$ years old, and the rest $23.4 \%$ are $41-<$ 61 years old. Furthermore, $72.3 \%$ of them spent under IDR 100,000 per visit, $24.54 \%$ of them spent IDR 100,000 - 200,000 and the rest 2.98\% spent more than IDR 200,000.

Table 1. Respondent Profile

\begin{tabular}{c|c|c}
\hline Gender & Male & $\mathbf{5 1 . 1 5 \%}$ \\
\hline Age & Female & $48.85 \%$ \\
\hline & $<18$ years old & $1.15 \%$ \\
\hline & $18-<22$ years old & $40.37 \%$ \\
\hline Last visit to the & $22-<41$ years old & $34.86 \%$ \\
\hline coffee shop & $41-<61$ years old & $23.17 \%$ \\
\hline & $>61$ years old & $0.46 \%$ \\
\hline & 1 month ago & $59.63 \%$ \\
\hline & 2 months ago & $22.94 \%$ \\
\hline Average Spending & 3 months ago & $7.57 \%$ \\
\hline & $>3$ months ago & $2.29 \%$ \\
\hline & $<$ IDR 100,000 & $7.57 \%$ \\
\hline
\end{tabular}

Source: Results of data processing.

Measurement Model. In the measurement model stage, the construct validity and reliability were evaluated. The validity evaluation was done by assessing convergent validity (average variance extracted $=\mathrm{AVE}$ ) and discriminant validity. Then, composite reliability was measured. Further, outer loading was also measured for all items of each construct. The following Table 2 shows the results of the evaluation of reliability, validity, and outer loading. The AVE ranges from 0.723 to 0.854 . The composite reliability ranges from 0.887 to 0.953 . Meanwhile, the outer loading value is between 0.797 to 0.937 . therefore, it could be concluded that all requirements have been met. 
Table 2. Reliability and validity evaluation

\begin{tabular}{|c|c|c|}
\hline Construct & Item & $\begin{array}{c}\text { Outer } \\
\text { Loading }\end{array}$ \\
\hline \multicolumn{3}{|c|}{ Brand Awareness $(\mathrm{AVE}=0.854 ; \mathrm{CR}=0.921)$} \\
\hline BA1 & This coffee shop has more complete facilities than other coffee shops. & 0.910 \\
\hline BA2 & This coffee shop is the best compared to other coffee coffees. & 0.937 \\
\hline \multicolumn{3}{|c|}{ Brand Image $(\mathrm{AVE}=0.723 ; \mathrm{CR}=0.887)$} \\
\hline BI1 & I feel this coffee shop is very well known to the public. & 0.823 \\
\hline $\mathrm{BI} 2$ & I feel this coffee shop has a prestigious image. & 0.876 \\
\hline $\mathrm{BI} 3$ & The manager of this coffee café can be trusted in service & 0.851 \\
\hline \multicolumn{3}{|c|}{ Brand Trust $(\mathrm{AVE}=0.834 ; \mathrm{CR}=0.953)$} \\
\hline BT1 & I trust the coffee shop brand & 0.888 \\
\hline BT2 & I feel this coffee shop can be trusted. & 0.924 \\
\hline BT3 & I feel this coffee shop offers a safe product. & 0.930 \\
\hline BT4 & I think this coffee shop has given as promised. & 0.910 \\
\hline \multicolumn{3}{|c|}{ Brand Loyalty $(\mathrm{AVE}=0.724 ; \mathrm{CR}=0.940)$} \\
\hline BL1 & I will state positive things about this coffee shop brand to others. & 0.797 \\
\hline BL2 & I would recommend this coffee shop to others. & 0.868 \\
\hline BL3 & I would encourage colleagues to visit this coffee shop. & 0.867 \\
\hline BL4 & I recommend this coffee shop to people I know. & 0.898 \\
\hline BL5 & I consider myself loyal to this coffee shop. & 0.823 \\
\hline BL6 & This coffee shop is a top choice for me among other coffee cafés. & 0.848 \\
\hline
\end{tabular}

Note: $\mathrm{AVE}=$ average variance extracted; $\mathrm{CR}=$ composite reliability

Source: Results of data processing.

Next, the discriminant analysis used criteria by Fornell-Larcker. The requirement that must be met is the AVE square root value must be greater than the correlation coefficient between constructs (Hair et al., 2017). Below, Table 3 shows that all square root values of each construct are greater than the correlation coefficient between constructs. Thus, all requirements have been met.

Table 3. Evaluation of Fornell-Larcker Criteria

\begin{tabular}{l|c|c|c|c}
\hline & Brand Awareness & Brand Image & Brand Loyalty & Brand Trust \\
\hline $\begin{array}{l}\text { Brand } \\
\text { Awareness }\end{array}$ & 0.924 & & & \\
\hline Brand Image & 0.684 & 0.850 & & \\
\hline Brand Loyalty & 0.620 & 0.571 & 0.851 & \\
\hline Brand Trust & 0.576 & 0.684 & 0.770 & 0.913 \\
\hline
\end{tabular}

Source: Results of data processing.

Apart from using the Fornell-Larcker criteria, (Hair et al., 2017) also recommended an evaluation with a Heterotrait-Monotrait (HTMT) ratio. (Hair et al., 2017) explained that 
the HTMT measurement is better than Fornell-Larcker criteria on the discriminant analysis. The requirement that must be met is that the HTM value must be less than 0.85 . The following Table 4 reveals that no HTMT value is more than 0.85 . Therefore, the requirements have been met.

Table 4. Evaluation of Heretroit-Monotrait (HTMT) Ratio

\begin{tabular}{l|c|c|c|c}
\hline & $\begin{array}{c}\text { Brand } \\
\text { Awareness }\end{array}$ & Brand Image & Brand Loyalty & Brand Trust \\
\hline Brand Awareness & & & & \\
\hline Brand Image & 0.819 & & & \\
\hline Brand Loyalty & 0.692 & 0.640 & & \\
\hline Brand Trust & 0.648 & 0.770 & 0.827 & \\
\hline
\end{tabular}

Source: Results of data processing.

Structural Model. The stages of the structural model evaluation consisted of measurement of collinearity issues, hypothesis testing, and coefficient of determination. Table 5 shows the results of collinearity evaluation. The results reveal that the requirement for VIF value to be below 5 can be met. The VIF value for each construct ranges from 1.878 to 2.462. Thus, there is no collinearity in the research model.

Table 5. Evaluation of Multicollinearity

\begin{tabular}{c|c|c|c}
\hline \multicolumn{2}{c|}{ As B Predictor } & \multicolumn{2}{c}{ As BL Predictor } \\
\hline Construct & VIF & Construct & VIF \\
\hline BA & 1.878 & BT & 1.962 \\
\hline BI & 1.878 & BA & 1.958 \\
\hline \multicolumn{2}{c}{ Note: BI = brand image; BT = brand trust; BL = brand loyalty } \\
\hline Source: Results of data processing.
\end{tabular}

The next analysis is hypothesis testing. It was done by considering the level of significance ( $\square=5 \%$ ) and testing using one-tailed test criteria. When the $\square$-value in the hypothesis is smaller than $\square=5 \%$, then the hypothesis can be supported empirically. However, if the value of $\square$-value is greater than $\square=5 \%$, then the hypothesis is not supported. Table 6 shows that all hypotheses are supported empirically, except the fifth hypothesis which states that brand image has a positive effect on brand loyalty. It is because the value of $\square$-value $=7.7 \%$ is greater than $\square=5 \%$. 
Table 6. Hypothesis testing

\begin{tabular}{l|c|c|c}
\hline \multicolumn{1}{c|}{ Hypothesis } & $\begin{array}{c}\text { Standardized } \\
\text { Path } \\
\text { Coefficient }\end{array}$ & $\square$-value & Decision \\
\hline $\mathrm{H}_{1}:$ The higher the brand awareness, the higher the brand image & 0.684 & 0.000 & Supported \\
\hline $\mathrm{H}_{2}:$ The higher the brand awareness, the higher the brand trust & 0.203 & 0.002 & Supported \\
\hline $\begin{array}{l}\mathrm{H}_{3}: \text { The higher the brand awareness, the higher the brand } \\
\text { loyalty }\end{array}$ & 0.299 & 0.000 & Supported \\
\hline $\mathrm{H}_{4}:$ The higher the brand image, the higher the brand trust & 0.546 & 0.000 & Supported \\
\hline $\mathrm{H}_{5}:$ The higher the brand image, the higher the brand loyalty & -0.080 & 0.077 & $\begin{array}{c}\text { Not } \\
\text { Supported }\end{array}$ \\
\hline $\mathrm{H}_{6}:$ The higher the brand trust, the higher the brand loyalty & 0.653 & 0.000 & Supported \\
\hline Source: Results of data processing. & &
\end{tabular}

The last evaluation is the evaluation of the coefficient of determination $\left(\mathrm{R}^{2}\right)$. Brand image has a coefficient of determination of $0.467\left(\mathrm{R}^{2}=46.7 \%\right)$, meaning that brand image can be explained by the brand awareness construct by $46.7 \%$, and the rest $53.3 \%$ is explained by other constructs. Furthermore, brand awareness and brand image constructs explain the brand trust construct by $49 \%$, while the rest $51 \%$ is explained by other constructs. Finally, the brand loyalty construct can be explained the construct of brand awareness, brand image, and brand trust by $64.2 \%$, and the rest $35.8 \%$ is explained by other constructs. Hair et al. (2017) categorized the value of the coefficient of determination $\left(R^{2}\right)$ for endogenous constructs which ranges from substantial $\left(R^{2}=0.75\right)$, moderate $\left(\mathrm{R}^{2}=0.50\right)$, to weak $\left(\mathrm{R}^{2}=0.25\right)$ category. Below, Table 7 shows that all endogenous constructs are in the moderate category.

Table 7. Evaluation of R-square $\left(\mathrm{R}^{2}\right)$

\begin{tabular}{c|c|c}
\hline Construct & $\mathbf{R}^{\mathbf{2}}$ & Category \\
\hline Brand Image & 0.467 & Moderate \\
\hline Brand Trust & 0.490 & Moderate \\
\hline Brand Loyalty & 0.642 & Moderate \\
\hline
\end{tabular}

Source: Results of data processing.

\section{DISCUSSION}

The first hypothesis, which states that the higher the brand awareness, the higher the brand image, is supported empirically. This result is consistent with the results of previous studies conducted by (Bilgin, 2018); (Saleem et al., 2015); and (Permana and Ilham, 2018). This revealed that brand awareness was able to improve the coffee shop brand image. Based on the respondents' profile, most of them could be considered as the younger generation of coffee shop lovers because they were at the age group of 18-22 years old, visited the coffee shop in less than 1 month and spent less than IDR 100,000. Thus, to increase the brand awareness, the coffee shops had to pay attention to their desires by providing suitable facilities. The efforts that must be made by the management of the coffee shop to increase their brand image were to complement and maintain the existing facilities such as providing enough sugar, creamer, spoons, tissues, comfortable 
tables and chairs, WIFI, electric plugs for Smartphone chargers, music and lights. Thus, the customer would be comfortable while they were discussing, reading or just relaxing.

Next, the second hypothesis, which states that the higher the brand awareness, the higher the brand trust, is supported empirically. This result is in accordance with the results of previous studies (Bilgin, 2018; Das, 2016; Han et al., 2015). When the management of the coffee shop seriously maintained their existing facilities, for example providing well-functioned electrical outlet, it was possible that the customers would increase their trust on the coffee shop. They would assume that it was such a safe place to visit. In addition, if the management could also focuse on maintaining a better environment for the coffee shop compared to the others, this could also help increasing their trust that the coffee shop committed in only providing the best for their customers.With this consistent performance, the credibility of the coffee shop would be well maintained.

In addition, the third hypothesis, which states that the higher the brand awareness, the higher the brand loyalty, is supported empirically. This result is in line with the studies by (Alkhawaldeh et al., 2017); (Alkhawaldeh and Eneizan, 2018); (Bilgin, 2018); (Das, 2016); (Kim et al., 2018); (Su, 2016); (Su and Chang, 2018); and (Tran et al., 2019). When the customers understood that the coffee shops had quality products and complete facilities, then they would be loyal, recommend, say positive things to others, and make the quality coffee shops to be the first choice among other coffee shops. Managing loyalty through brand awareness was important because the competition among coffee shops also included providing facilities, offering interesting menus and focusing the growth of new coffee shops. Therefore, the management must innovate to make the coffee shops unique compared to the others. For example, they could provide a large television with channels broadcasting world soccer matches. With such uniquenesses, the customer loyalty would simultaneously increase, especially among the football lovers.

Further, the fourth hypothesis, which states that the higher the brand image, the higher the brand trust, is also supported empirically. This result is in accordance with studies by (Chinomona, 2016); (Lee and Jee, 2016); and (Liu et al., 2019). The brand image could guarantee brand trust. All indicators on the brand image must be wellmanaged to increase the brand trust. For example, the management must strive to make their coffee shop popular. In addition, the coffee shops must also have a good image or continue to increase their brand awareness. They must also pay attention to the services. Besides offering good coffee products, the coffee shop services must also be good and consistent. The employees must be able to provide continuous good service, for example by being polite, friendly, error-free, and fast-response in ordering to maintain the customers' trust. Further, a prestigious, famous, and trusted coffee shop could predict their brand trust. When the brand image was getting weaker, it could have an impact on the decline in customer confidence towards the brand.

Besides, Table 6 reveals that brand awareness and brand image influence brand trust. The hypothesis test results show that the brand image had a greater influence than brand awareness. Therefore, it was important for the coffee shop management to continue to maintain and enhance its brand image through the best services consistently from time to time. Thus, a prestigious title would be attached to the coffee shop and in the end, the coffee shop brand would get a high trust from the customers. Another thing that needed to 
be improved was to make the name of the coffee shop well-known to the wider community through, for example, an intensive marketing communication.

Furthermore, Table 6 also explains that the higher the brand image, the higher the brand loyalty would be. However, it is not in accordance with the research results by (Alkhawaldeh and Eneizan, 2018); (Espinosa et al., 2018); (Kim et al., 2018); (Lee et al., 2017); (Lin et al., 2017); and (Liu et al., 2019); (Semadi and Ariyanti, 2018). An increasing or decreasing brand image had no direct impact on brand loyalty. In fact, brand image was not a predictor of brand loyalty, but brand awareness and brand trust. The last hypothesis testing shows that the higher the brand trust, the higher the brand loyalty would be. This is consistent with (Chinomona, 2016); (Lee and Jee, 2016); (Liu et al., 2019); (Menidjel et al., 2017); (Semadi and Ariyanti, 2018). Table 6. reveals that there are two constructs that directly influence brand loyalty, including brand awareness and brand trust. The result of this study - which show that most of the respondents spent less than IDR 100,000 - had implied that when the brand image increased, the facilities provided would bring an impact on the price of the product which could be higher than the customer's personal budget. However, if the brand image was increased, it was still uncertain that the customers would make a purchase as many made the coffee shops as a meeting point or they were just being invited by friends. Therefore, it would not bring any influence on the brand loyalty. Further, based on the standardized path coefficient, the coefficient of brand trust $(0.653)$ is greater than the brand awareness coefficient $(0.299)$. Thus, it could be concluded that brand trust played a big role in increasing brand loyalty.

In the research model, it could also be concluded that from all hypotheses, only one hypothesis of brand image and brand loyalty which has no positive effect. The research model also shows that when the brand image increases, the brand image, brand trust, and brand loyalty will also increase. Therefore, the coffee shop must prioritize its brand awareness in the coffee shop management operations to maintain the regular customer and even increase their loyalty to the coffee shop brand.

\section{CONCLUSION}

Based on the results of data analysis, it can be concluded that the higher the brand awareness, the higher the brand image, brand trust and brand loyalty. This indicates that brand awareness has an important role to predict brand image, brand trust and brand loyalty. The most important priority of coffee shop management here is how to increase brand awareness of the coffee shop. However, the high brand image does not also affect the high brand loyalty and vice versa. No matter how good or bad the brand image of a coffee shop will not have an impact on increasing or decreasing brand loyalty. Brand image is not a good predictor of brand loyalty.

The next conclusion is the higher the brand image, the higher the brand trust. This means that coffee shop management must have a strong commitment to maintaining a good brand image so that brand trust is also good. Finally, when brand trust increases, brand loyalty also increases. The impact of brand trust can ultimately increase brand loyalty from customers. This brand loyalty is most important for coffee shops because brand loyalty can increase total sales and lead to an increase in coffee shop profits. 


\section{REFERENCES}

Aaker, D. (2007). Managing brand equity. New York: Free Press.

Aaker, D. (2015). Aaker on branding: 20 Prinsip esensial mengelola dan mengembangkan brand. Jakarta: PT. Gramedia Pustaka Utama.

Algesheimer, R., Dholakia, U. M., and Herrmann, A. (2005). The social influence of brand community: Evidence from European car clubs. Journal of Marketing, 69(3), 19-34. doi:10.1509/jmkg.69.3.19.66363.

Alkhawaldeh, A. M., Al-Salaymeh, M., Alshare, F., and Eneizan, B.M. (2017). The effect of brand awareness on brand loyalty: Mediating role of brand commitment. European Journal of Business and Management, 9(36), 38-47.

Alkhawaldeh, A.M., and Eneizan, B.M. (2018). Factors inluencing brand loyalty in durable goods amrket. International Journal of Academic Research in Business and Social Sciences, 8(1), 326-339.

Al-Msallam, S. (2015). Customer satisfaction and brand loyalty in the hotel industry. European Scientific Journal October 2015 SPECIAL edition Vol.1: 232-251.

Awan, A. G. (2014). Impact of customer satisfaction on brand loyalty an empirical analysis of home appliances in Pakistan. British Journal of Marketing Studies Vol.2, No.8: 18-32.

Aydin, S., Özer, G., and Arasil, Ö. (2005). Customer loyalty and the effect of switching costs as a moderator variable. Marketing Intelligence \& Planning, 23(1), 89 103. doi:10.1108/02634500510577492.

Bart, Y., Shankar, V., Sultan, F., and Urban, G. L. (2005). Are the Drivers and Role of Online Trust the Same for All Web Sites and Consumers? A Large-Scale Exploratory Empirical Study. Journal of Marketing, 69(4), 133 152. doi:10.1509/jmkg.2005.69.4.133.

Bella, A. (2018). Mencicipi bisnis restoran Indonesia 2019. Marketeers. https://marketeers.com/mencicip-bisnis-restoran-indonesia-di-2019/

Bilgin, Y. (2018), The effect of social media marketing activities on brand awareness, brand image and brand loyalty. Business \& Management Studies: An International Journal, 6(1), 128-148. doi: http://dx.doi.org/10.15295/bmij.v6i1.229

Broadbent, S., Bridson, K., Ferkins, L., and Rentschler, R. (2010). Brand love, brand image and loyalty in Australian elite sport. Australian and New Zealand Marketing Academy, 1-9. Retrieved from http://anzmac2010.org/proceedings/pdf/anzmac10Final00293.pdf, accessed: June $15,2020$.

Cassia, F., Cobelli, N., and Ugolini, M. (2017). The effects of goods-related and servicerelated B2B brand images on customer loyalty. Journal of Business \& Industrial Marketing, 32(5), 722-732. doi:10.1108/jbim-05-2016-0095 .

Chaudhuri, A., and Holbrook, M. B. (2001). The chain of effects from brand trust and brand affect to brand performance: The role of brand loyalty. Journal of Marketing, 65(2), 81-93. doi:10.1509/jmkg.65.2.81.18255 .

Chinomona, R. (2016). Brand communication, brand image and brand trust as antecedents of brand loyalty in Gauteng Province of South Africa. African Journal of Economic and Management Studies, 7(1), 124-139. doi:10.1108/ajems-03-2013-0031.

Das, G. (2016). Antecedents and consequences of trust: an e-tail branding perspective 
International Journal of Retail and Distribution Management, 44(7), 713-730. https://doi.org/10.1108/IJRDM-06-2015-0089.

Direktorat Jenderal Perkebunan. (2015). Statistik perkebunan Indonesia tahun 2014-2016.

Espinosa, J. A., Ortinau, D. J., Krey, N., and Monahan, L. (2018). I'll have the usual: how restaurant brand image, loyalty, and satisfaction keep customers coming back. Journal of Product \& Brand Management. doi:10.1108/jpbm-10-2017-1610.

Fullerton, G. (2009). The Impact of brand commitment on loyalty to retail service brands. Canadian Journal of Administrative Sciences / Revue Canadienne Des Sciences del'Administration, 22(2), 97-110.

Hair, J.F., Hult, G.T.M., Ringle, C.M., and Sarstedt, M. (2017). A primer on partial least squares structural equation modeling (PLS-SEM). Los Angeles: SAGE.

Han, S. H., Nguyen, B., and Lee, T. J. (2015). Consumer-based chain restaurant brand equity, brand reputation, and brand trust. International Journal of Hospitality Management, 50, 1-10.

Hawkins, M. (2013). Customer behavior building marketing strategy. Mc.Graw Hill.

Herlyana, E. (2012). Fenomena coffee shop sebagai gejala gaya hidup baru kaum muda. Jurnal THAQÃFIYYÃT, Vol. 13, No. 1 Juni 2012:188-204.

Ika, N, and Kustini (2011). Experiental marketing, emotional branding, and brand trust and their effect on loyalty on Honda motorcycle product. Journal of Economics, Business, and Accountancy Ventura, Vol. 14, No. 1, April 2011:19-28.

Kardes, Cronley, and Cline (2010). Consumer behavior. Cengage Learning.

Kim, S. (Sam), Choe, J. Y. (Jacey), and Petrick, J. F. (2018). The effect of celebrity on brand awareness, perceived quality, brand image, brand loyalty, and destination attachment to a literary festival. Journal of Destination Marketing \& Management, 9, 320-329. doi:10.1016/j.jdmm.2018.03.006

Kotler, P., and Keller, K.L. (2009). Manajemen pemasaran. Jakarta: Erlangga.

Kotler, P., and Keller, K.L. (2016).Marketing management, 15th Edition. New Jersey: Pearson Pretice Hall, Inc.

Lee, C.-Y., Chang, W.-C., and Lee, H.-C. (2017). An investigation of the effects of corporate social responsibility on corporate reputation and customer loyalty evidence from the Taiwan non-life insurance industry. Social Responsibility Journal, 13(2), 355-369. doi:10.1108/srj-01-2016-0006.

Lee, H.-J., and Jee, Y. (2016). The impacts of brand asset of domestic screen golf playing systems upon brand trust and brand loyalty. International Journal of Sports Marketing and Sponsorship, 17(4), 320-332. doi:10.1108/ijsms-11-2016-021

Lin, J., Lobo, A., and Leckie, C. (2017). Green brand benefits and their influence on brand loyalty. Marketing Intelligence \& Planning, 35(3), 425-440. doi:10.1108/mip-092016-0174.

Liu, M. T., Liu, Y., Mo, Z., Zhao, Z., and Zhu, Z. (2019). How CSR influences customer behavioural loyalty in the Chinese hotel industry. Asia Pacific Journal of Marketing and Logistics. doi:10.1108/apjml-04-2018-0160.

Mahmoudzadeh, S., Bakhshandeh, G., and Ilkhechi, M. (2013). Exploring the effect of brand identity on purchase intention in cell phone market in Iran. International Journal of Management and Humanity Sciences, 2(S), 1165-1173.

Mao, J. (2010). Customer brand loyalty. International Journal of Business and Management Vol. 5, No. 7; July 2010: 213-217. 
Mardianto, A. (2011). Akibat hukum pembatalan pendaftaran merek terhadap hak penerima lisensi merek menurut UU No. 15 Tahun 2001. Jurnal Dinamika Hukum, 11(3), 444-452.

Mathew, V., Ali, R.T.M., and Thomas, S. (2014). Loyalty intentions does the effect of commitment, credibility and awareness vary across consumers with low and high involvement?. Journal of Indian Business Research, 6(3), 2014 pp. 213-230

Menidjel, C., Benhabib, A. and Bilgihan, A. (2017). Examining the moderating role of personality traits in the relationship between brand trust and brand loyalty. Journal of Product \& Brand Management, 26(6), 631-649.

Morgan,R. M., and Shelby D. H. (1994).The commitment-trust theory of relationship marketing. Journal of Marketing, Vol. 58, July: 20-. 38.

Mudzakkir, M. F., and Nurfarida, I. N. (2015). The Influence of Brand Awareness on Brand Trust Through Brand Image. SSRN Electronic Journal. doi:10.2139/ssrn.2670597

Permana, R.M., and Ilham (2018). Antecedents and consequences pf brand iamge: A ase of a packaged drinkig water product. The 2018 International Confwerence of Organizational Innovation, KnE Social Sciences, 209-219. doi:10.18502/kss.v3i10.3374.

Potensi bisnis kafe sentuh USD 4,16 milliar. (2016). JPNN.com. Retrieved July 29, 2019, https://www.jpnn.com/news/potensi-bisnis-kafe-sentuh-usd-416-miliar.

Reichheld, F. F., and Schefter, P. (2000). E-loyalty your secret weapon on the Web. Harvard Business Review, 78(4), 105-113.

Ringle, C. M., Wende, S., and Becker, J. M. (2015). SmartPLS 3. Bönningstedt: SmartPLS. Retrieved from http://www.smartpls.com.

Rizan, S. (2012). Pengaruh brand image dan brand trust terhadap brand loyalty teh botol sosro. Jurnal Riset Manajemen Sains Indonesia, Vol 3 No.1, 2012: 1-17. Jakarta: Universitas Negeri Jakarta.

Salciuviene, L., Ghauri, P. N., Mockaitis, A. I., and De Mattos, C. (2009). Brand image perceptions across cultures: A study of symbolic and functional associations. Advances in International Marketing, 20, 177-191.

Saleem, S., Rahman, S.U., and Umar, R.M. (2015). Measuring customer based beverage brand equity: Investigating the relationship between perceived quality, brand awareness, brand

Salendra. (2014). Coffee shop as a media for self-actualization today's youth. Jurnal Messenger, Volume VI, Nomor 2, Juli 2014:49-58.

Sangadji dan Sopiah. (2013). Perilaku konsumen : Pendekatan praktis disertai himpunan jurnal penelitian. Yogyakarta : Andi

Schivinski, B., and Dabrowski, D. (2015). The impact of brand communication on brand quity through Facebook. Journal of Research in Interactive Marketing, 9(1), 31 53. doi:10.1108/jrim-02-2014-0007

Semadi, I.P., and Ariyanti, M. (2018). The influence of brand experience, brand iamge and brand trust on brand loyalty of ABC-CASH. Asian Jorunal of Management Sciences \& Education, 7(3), 12-23.

Setyawan, J. L., dan Adiwijaya, M. (2018). Pengaruh brand awareness, brand experience, dan word of mouth terhadap purchase decision pada konsumen Baskhara Futsal arena Surabaya. AGORA, 6(1). 
Sorayaei, A., and Hasanzadeh, M. (2013). Impact of brand personality on three major relational consequences (trust, attachment and commitment to the brand): Case study of Nestle Nutrilion company in Tehran, Iran. Word Applied Sciences Journal, 28(11):79-87.

$\mathrm{Su}, \mathrm{J}$. (2016). Examining the relationships among the brand equity dimensions: Empirical evidence from fast fashion. Asia Pacific Journal of Marketing and Logistics, 28(3), 464-480. https://doi.org/10.1108/APJML-01-2015-0004

$\mathrm{Su}$, J. and Chang, A. (2018) Factors affecting college students' brand loyalty toward fast fashion: A consumer-based brand equity approach. International Journal of Retail \& Distribution Management, 46(1), 90-107. doi: 10.1108/IJRDM-01-2016-0015

Tran, V. T., Nguyen, N. P., Tran, P. T. K., Tran, T. N., and Huynh, T. T. P. (2019). Brand equity in a tourism destination: a case study of domestic tourists in Hoi An city, Vietnam. Tourism Review. doi:10.1108/tr-08-2017-0130 